\title{
ENTREPRENEURSHIP ON STRATEGIES TO BUILD COMPETITIVE ADVANTAGES OF RIAU SPECIALTY FOOD PRODUCTS
}

\author{
Fatkhurahman \\ fatkhurrahman@unilak.ac.id \\ Universitas Lancang Kuning \\ J1. Yos Sudarso No.KM. 8, Umban Sari, Rumbai, \\ Pekanbaru, Riau 28266 \\ Sidik Priadana \\ Ellen Rusliati \\ Universitas Pasundan \\ Jl. Tamansari No.6-8, Tamansari, Kec. Bandung Wetan, \\ Kota Bandung, Jawa Barat 40116
}

received: 12/4/19; revised: 18/4/19; published: 29/6/19

\begin{abstract}
The competitive advantage of small and medium industries (SMIs) is a concern in the preparation to face the conditions of developing and growing into large industries. This research, conducted in Riau Province with regard to competitive advantage of SMIs, can provide an overview of the real conditions in the Indonesian border region. Survey was conducted to 247 respondents of small and medium food industry managers using questionnaires. The collected data were analyzed using SEM WarpPLS analysis. The results showed that the competitive advantage of small and medium food industries in Riau Province proved to be influenced by the application of superior strategies, thus, the use of superior strategies was needed to achieve competitive advantage. An effective strategy for business managers is to build entrepreneurship of the business managers through building the ability to see market opportunities and also courage in facing competitors with various risks.
\end{abstract}

Keywords: competitive advantage; applying effective strategy; entrepreneurship

\section{INTRODUCTION}

A business manager is the spearhead in the survival, development, and advancement of a business. Maintaining a business is not an easy task, because businesses that survive are businesses that are ready to face various forms of challenges in producing products, marketing the products, and also sustaining the marketing in every time period. The survival of a business is also an achievement in managing a business, not only for growing small businesses, but also for medium and large businesses. As an example in Indonesia, based on information from Tribunpekanbaru.com, Jakarta: "Its incapability to compete in the digital era is said to be the cause of bankruptcy of PT Nyonya Meneer which was established in 1919."

The company stood for more than a century and in its time was the market leader. This case is related to competition and the changing science and knowledge, namely the internet technology. This technology is a source of havoc for large companies in the face of current global competition. A company can have achievements in business using various measures and strategies to be able to face global competition.

Business managers are also faced with problems in development. In the development phase, businesses face various problems as through the company's ability to survive, they will try to expand their marketing area, and also do everything in their power to show their identity to continue to grow and introduce various products. For companies that face various existing problems, they need to be careful in selecting the strategy that the company will use to face real conditions. For example, whether they act as followers and/or they actually have unique products and have courage in establishing themselves as market leaders.

In the growing conditions of the company, it is also an aging phase and also makes the company always needs to be prepared in advance to deal with various forms of success and continue to prepare and foster the company's heirs and prepare them. The heir of the business manager is a form of challenge for how the company can continue its business and be inherited by its heirs in the future. The problem faced 
by large companies is always on the unreadiness of the successors to continue the struggle of the companies that continuously face challenges and to be ready to lead the market.

The analogies are the real conditions experienced by company managers, especially SMI companies that are currently in the period of survival. In the cycle, a small-size company that is able to survive will have the possibility to progress and develop into a medium-sized company, and a medium-sized company that is able to develop may grow into a large company and lead the market. This logic is formed in having a survival attitude from existing small entrepreneurs. It is impossible for business managers to be able to make achievements into large companies while the ability to survive in the small business phase is still difficult to gain.

The natural case is the small and industries (SMIs) in Riau Province. Since SMIs are the basis of the economy, the government's protection for them is strong enough and so as the partnership between medium and large companies and the SMIs. This condition turns the SMIs into a spoiled child who seems to only be able to suckle on their mothers. This is also stated in the Law No. 22 of 2008 concerning Micro, Small, and Medium Enterprises (MSMEs) and also strengthened by the Law No. 3 of 2014 concerning Industry and Government Regulation No. 6 of 2015 concerning the Creative Economy Agency.

All of mentioned laws are forms of support provided by the government and large companies in developing SMIs. These regulations coupled with regulations on the provision of capital support from banking service companies that provide significant contribution in building an economy based on the people.

In terms of SMIs engaging in the food sector in Riau Province, data showed that the development of business units decreased by $8 \%$ in 2012 and continued to decline in 2014 by $9.3 \%$. This decrease in business units was followed by a decrease in employment in 2012 as much as 5\% and in 2014 it dropped dramatically to $70 \%$. However, in terms of investment and production, they continued to increase. The investment increased by $45 \%$ and production by $67 \%$ (Directorate of Industry and Trade of Riau Province, 2010, 2012, 2014).

Based on the data, the business movements of SMIs in Riau Province has led more to the use of capital rather than the use of human resources (HR). This condition is different from the 1997 and 2008 crisis where SMIs were more labor intensive rather than capital intensive. This is a fact that the policies on SMIs have changed because of the various existing challenges. However, the case of developing the SMIs is a different phenomenon. Viewed from the condition that they have a decrease in the use of human resources and more use of technology and capital, human resources need to develop their competitiveness.
Competitiveness of human resources is related to the entrepreneurial spirit. Today, the entrepreneurial spirit is a concern and a driver for a company to survive (Suhendar, 2013). On the part of the business managers, the audacity to take risks coupled with the ability to identify opportunities becomes a form of ability or competitiveness that should be possessed in order to build and achieve the effectiveness of business. In the case of the developing food industry, the Riau Province government has a strategic vision of making Riau Province a tourism development because Riau's location is in the outermost area and borders on neighboring countries and it is the entrance for neighboring countries.

The opportunities that are seen are visits by foreign tourists to Riau and since it has a variety of culinary products. These culinary products are also an attraction in the region in developing its superior products. However, the problem faced by the SMI managers in seeing these opportunities is the emergence of a variety of products from neighboring countries as a form of variation and becomes a choice for visitors of Riau. Products such as food from Malaysia, Singapore, Thailand, and China have dominated and have taken away attention from local products.

The uniqueness of local products is also experiencing various obstacles in terms of production. This can be seen from the problem of availability of raw materials and that some of them are not unique raw materials from Riau. This obstacle becomes a problem that needs attention. How to shape the uniqueness of food products as original to Riau region, and can effective strategies build unique products and whether entrepreneurship (being able to see opportunities and taking risks) can make effective strategies in dealing with product competition that varies greatly in Riau.

The model built is based on several previous research. Siregar (2015) explained that the strategy used to improve competitive advantage was through optimization of human resources. Then it is also reinforced by Suendro (2010) stating that the ability to innovate for human resources is the first step to make SMIs superior in a sustainable manner. Supranoto (2009) also stated that the ability of business managers to build a network is still not optimal and business competitiveness is still questionable.

Regarding the issue of entrepreneurship development as a resource in order to implement effective business strategies, Brouthers, K. D., Nakos, G., \& Dimitratos, P. (2015) explained that through the development of entrepreneurship globally which is in seeing opportunities and the courage to try new things will have an impact on performance through the implementation of effective business strategies. Similarly, Eggers, F., Kraus, S., Hughes, M., Laraway, S., \& Snycerski, S. (2013) suggested that a broader entrepreneurial orientation will open views and opportunities and in turn will have an impact to the performance of small businesses. 
The audacity to try new things was discussed by Kreiser, P.M., Marino, L. D., Dickson, P., \& Weaver, K. M. (2010) stating that entrepreneurs who dare to face risks in business will think of trying the most effective way of doing business. Tang, Z., \& Tang, J. (2012) stated that a broad view of entrepreneurship would encourage forming the most appropriate strategy in doing business. Explained by Kraus, S., Rigtering, J. C., Hughes, M., \& Hosman, V. (2012), the strengthened global views has an impact on the use of good business strategies.

Moreover, regarding the impact of the implementation of effective strategies related to the ability to build superior advantages, Machmud (2013) stated that strategies that give birth to policies in business will result in success of the SMIs and it can be carried out continuously. Djodjobo (2014) stated that business performance built from the development of entrepreneurial resources has a significant effect on competitive advantage in order to improve the uniqueness of the products by considering consumer needs. Pailis (2016) believed that the courage to take risks is a form of real effort by a business manager in order to address the success of the business to produce innovative products.

According to Islam, M. A., Khan, M. A., Obaidullah, A. Z. M., \& Alam, M.S. (2011), the characteristics of entrepreneurs in small businesses who dare to take risks and are also able to read opportunities and creative characters in developing strategies that are possible to implement will have an impact on product uniqueness. Hazlina et al. (2010) state that the competencies possessed by an entrepreneur in entrepreneurship have a strong relationship to the success of building a superior business. Similarly, Tang, Z., \& Hull, C. (2012) stated that the orientation of seeing business opportunities for entrepreneurs and the strategies used had an impact on their ability to survive in small businesses.

Cassia, L., \& Minola, T. (2012) stated that the growth and development of MSMEs is closely related to entrepreneurial views and the strategies used. Anderson, B. S., \& Eshima, Y. (2013) also conveyed that the excellence in business is closely related to the abilities possessed by an entrepreneur. Shirokova, G., Vega, G., \& Sokolova, L. (2013) affirmed that business strategy has an impact on business performance itself.

Based on the previously produced model, it can be said that there has not been any unique study on industrial products in the tourism sector. The effectiveness of the implemented strategies as well as the use of entrepreneurship variables (the ability to see opportunities and the courage to take risks to produce unique products) are also the novelty of this study.

Entrepreneurship characterizes business management development in business. According to Suryana (2008), the development of entrepreneurial spirit in the form of the character of courage to take risks and also the ability to see opportunities will be able to produce creative and innovative products in achieving success. This is reinforced by Kristanto (2009) stating that entrepreneurship is the lifeblood of the process of producing creative products in the economy. According to Zimmerer (2008), an entrepreneur becomes the basis for creating product creativity in order to achieve excellence and will be able to develop business. Suhendar (2013) states that doing what is normal is not an entrepreneur, but those who truly do what they believe are those who have entrepreneurial spirit.

According to Suryana (2008), entrepreneurial spirit is a character possessed by a business manager in the form of courage to face various possibilities of ideas in the form of strategy implementation in business. Alma (2010) states that the ability to produce creative products is the basis for an entrepreneur, and then the product is a manifestation of its effectiveness in doing business and it is also a real effort to develop human resources in looking at opportunities and also in developing courage to take risks. These are all definitions of entrepreneurship.

A similar statement was delivered by Dewanti (2008) that there are many common factors in producing innovative products, namely individual factors, environmental conditions, role models, and coordinated activities. These conditions are the basis for building entrepreneurial characteristics such as their ability to see opportunities and also their courage in making them happen. Entrepreneurship is a situational condition and it continues to shift and it is a characteristic of life process. She elaborates that there are several characteristics of entrepreneurial power skills, including: 1) the ability to manage risk; 2) the ability to select businesses according to their preferences; 3) the ability to manage time; 4) the ability to manage inner strength; 5) the ability to utilize feedback; 6) the ability to increase knowledge; 7) the ability to communicate and convince others; 8 ) mastery of creativity/innovation techniques; and 9) achievement oriented. Frinces (2011) adds the ability to calculate quickly and precisely the beneficial possibilities of the exploitation of the potentials, resources, and opportunities.

Based on the aforementioned opinions about entrepreneurship, the focus of this research is the ability to manage risk and the ability to calculate quickly and precisely the likelihood benefits of exploiting the potentials, resources, and opportunities in the form of being able to see opportunities.

The ability to see opportunities in this case is the small business managers' ability to see existing opportunities, capture new opportunities, and direct efforts towards the opportunities. The elements include: seeing opportunities, and capturing and realizing the opportunities.

The audacity to take risks is the business managers' 
courage in starting a business quickly and also readiness to face the possibility of failure, yet still learning from the experienced failures. Therefore, the element of courage to take this risk includes: realizing business ideas without too much thinking; readiness to face failure; and effort to mend failures.

Then on the subject of business effectiveness strategies, Wheelen, et. al. (2010) states that a success in business cannot be separated from the important role of policy. A wise decision making by considering many factors both internal and external will help a business achieve the effectiveness of its business performance, thus excellence in the form of product innovation will be realized. Similarly, Wahab (2012) explains that a results-oriented business policy should consider many things so that policy outcomes are more effective.

Based on the concept of the strategy that is associated with effectiveness in business management, then clearly a strategy is a method used in order to achieve desired goals. In this research, strategy is defined as the effectiveness in managing business.

Effectiveness is the maximized level of use of organizational resources (labor, money, and technology) in order to increase the yield of each unit of resources. The elements include: the use of labor, budget, and technology.

Competitive advantage is the unique position of an organization in developing competitiveness through patterns of resource deployment. The indicators of business excellence include product excellence, price excellence, service excellence, and innovation excellence. Zimmerer (2008) suggests that excellence can be realized through the realization of creativity in making product innovation. Therefore, it can be said that this business excellence is seen from the perspective of uniqueness of the products.

Uniqueness of the resources means that the products do not yet exist in other regions, and if they do, it would still be different and contain their own uniqueness. The elements include: taste, packaging, raw materials, and manufacturing process.

\section{METHODS}

In this article, survey was carried out and the samples were taken from the population of 650 SMI managers of food products in Riau Province spread over ten regencies/cities namely Bengkalis, Siak, Rokan Hilir, Indragiri Hilir, Pelalawan, Islands Meranti, Taluk Kuantan and Kampar Regencies, and Pekanbaru and Dumai Cities. Whereas, Indragiri Hulu and Rokan Hulu Regencies were not included in the list of areas that have unique souvenir products and the regencies were represented by other regencies, namely Indragiri Hulu was represented by Indragiri Hilir and Rokan Hulu was represented by Rokan Hilir. The samples were 247 people and the number was obtained using the Taro Yamane formula with 5\% significance level. The sampling technique used was cluster proportional random sampling technique. This cluster technique is based on the type of souvenir products produced in each Regency/City and taken proportionally according to the number of distributions found in each region and random sampling was taken from the distribution of populations in the area. The variables in this research include competitive advantage (unik_pro), the implementation of effective strategies ( $e f e k$ us), entrepreneurship (peluang) and risk taking (brani_ri ri). The data collection instrument was a questionnaire compiled based on the operationalization of research variables using variables of opportunity and the risk taking as independent variables. The business effectiveness variable is the intervening variable and the variability of product uniqueness as a form of competitive advantage is the dependent variable. The data processing technique was a quantitative technique namely Structural Equation Modeling (SEM) analysis using WarpPLS program.

\section{RESULTS}

Based on the results of the questionnaire distributed to 247 respondents of the food SMI managers in Riau Province, the respondents have several characteristics. In terms of the length of time running the business, 57\% of respondents had run the business for less than 10 years. Based on level of education, $63 \%$ had secondary school education. Based on partnership, $86 \%$ of the business managers had partnered for less than 10 years. The data shows that the respondents in this research were business managers who were still relatively young, had secondary education, had a partnership with both medium and large companies through the Corporate Social Responsibility (CSR) program, and had partnered with local governments through coaching programs from the government.

The competitive advantage (unik_pro) variable is described as products that do not yet exist in other areas and if they do exist, they are different and have their own uniqueness. In the four indicators, the average score was 3.5 , which was in the good category, with the highest indicator being uniqueness of taste, while the lowest indicator being product packaging. The effective strategy implementation variable (efek_us) is the maximum usage level of business resources (labor, money, and technology) in order to increase the yield of each unit of resources. In the three indicators used, it was found that the average score was 3.3, which was in the moderate category, with the highest indicator being the use of labor while the lowest indicator being the use of technology. Moreover, the entrepreneurship (peluang) variable in this case is the small business managers who see opportunities, 
seizes new opportunities and directs the business towards the opportunities. In the three indicators, the average score was 3.45 , which was in the good category, with and the highest indicator being in the ability to see opportunities while the lowest indicator being the ability to realize opportunities. Finally, in the entrepreneurship trait of having the courage to take risks (brani_ri), which is the courage that the business managers have in starting a business quickly and their readiness to face the possibility of failure, but still learns from the experiences of failures. The indicators used were three indicators with an average score of 3.2, which was in the moderate category with the highest indicator being ready to face failure while the lowest being not ready to face failure.

The research data was tested for validity, reliability, and normality tests. The results of the validity test showed that the questionnaire about the competitive advantage variable (unik_pro) with four indicators, the implementation of effective strategy variable (efek $\_$s) with three indicators, the entrepreneurship variable (peluang) with three indicators, and risk taking courage (brani_ri) with three variables consisting of 13 indicators were declared valid because the rcount value was greater than the rcritical value of 0.300 . While in the reliability test, the reliability coefficient of the research instrument was greater than 0.600 and exceeds the standard, which means that the instrument (questionnaire) used was valid and reliable. From the normality test, it was found that the Asymp value obtained from the calculation results for the peluang $=0.227$; brani_ri $=0.064$; efek_us $=$ 0.062 , and unik pro $=0.066$, which are greater than the value of the significance level of 0.05 , hence, the sample data comes from a population that are normally distributed.

Feasibility assessment of questionnaires and research data and description of each research variable were carried out. The data were then analyzed and tested for hypotheses based on SEM using WarpPLS. The results of the full models are presented in Figure 1.

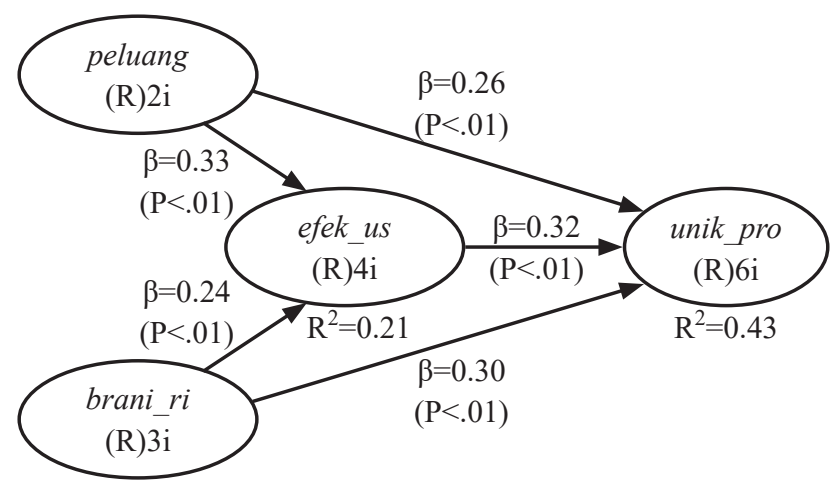

Figure 1. Full Model of the Influence of Entrepreneurship on Strategies for Building Competitive Advantage
Regarding the value of each relationship of all research variables, they had a close relationship between one and another, and each coefficient showed the influence of independent variables on the dependent variable. From the data, it can be seen that the competitive advantage seen from the uniqueness of food products in Riau was indicated to be influenced by the manager's ability to see opportunities $(\mathrm{P}<0.01)$. It was also influenced by the courage to take the risk of business managers in dealing with competitors from within and outside the country $(\mathrm{P}<0.01)$. In addition, both of these variables (ability to see opportunities and the courage to take risks) also had significant effects on effective strategies implemented by SMI business managers $((\mathrm{P}<0.01)$ and $(\mathrm{P}<0.01))$. Effective strategies had a significant influence on competitive advantage $(\mathrm{P}<0.01)$.

The influence of the ability to see opportunities for business managers was greater than the courage in taking risks $(0.33: 0.24)$. Thus, both variables (the ability to see opportunities and the courage to take risks), contribute to effective strategy as much as $21 \%$ and to competitive advantage as much as $43 \%$. This shows that competitive advantage was influenced by the application of effective strategies, and effective strategies was influenced by the ability to see opportunities and the courage to take risks in facing competition with similar products.

Drawn from the structural model of the influence of entrepreneurship on effective strategies of business managers of food business in Riau Province, the proposed hypothesis is as follows: Entrepreneurship in the form of the ability to see opportunities and the courage to take risks influences the implementation of effective strategies both partially and simultaneously. The results of the equation using WarPLS program are as follows:

$$
\eta_{1}=0,33 * \xi_{1}+0,24 * \xi_{2},+\zeta_{1}, \mathrm{R}^{2}=0,21
$$

From the equation, it is known that the variable of implementation of effective strategies in managing small industries of Riau food souvenirs was positively influenced by the ability of business managers to see opportunities with path coefficient values of 0.33 , and courage to take risks at 0.24 .

Of the two variables that have a positive effect on the implementation of effective strategies for food souvenirs typical of Riau, it can be seen that the most dominant influence was the ability to see opportunities rather than the courage to take risks. Simultaneously, the influence of these two variables was $21 \%$. Meanwhile, the remaining $79 \%$ was influenced by other factors not examined in this research.

The results of the path coefficient model of entrepreneurship variable namely peluang, brani_ri, 
and efek_us on unik_pro, are stated in the hypothesis: The ability to capture opportunities and courage to take risks as well as implementation of effective strategy influences competitive advantages both partially and simultaneously. The equation model is as follows:

$$
\eta_{2}=0,26 * \xi_{1}+0,36 * \xi_{2},+0,32 * \eta_{1}+\zeta_{2}, R^{2}=0,43
$$

The equation shows that the ability to capture opportunities had an effect of 0.26 which means that the variable had a positive effect on competitive advantage, the courage to take risks variable at 0.36 which had a positive effect, and the effective strategy for influencing business variables at 0.32 which also had a positive effect. Of the three variables that affected competitive advantage, it is known that courage to take risks had the largest influence on competitive advantage. This means that the bolder the business manager tries new things in producing processed products that are original of the region, the more superior the products.

Of the three variables, it can be seen that the amount of contribution to competitive advantage was $43 \%$. This shows that there were $57 \%$ of other variables that affected the competitive advantage of food products typical of Riau which were not examined in this study.

\section{DISCUSSION}

The specialty food SMIs in Riau Province are spread in the cities and regencies including Bengkalis Regency with lempok durian, Kepulauan Meranti regency with sago noodles, Indragiri Hilir Regency with amplang and banana chips, Indragiri Hulu Regency with dodol kedondong, Kuantan Singingi Regency with kelamai pulut, Kampar Regency with patin fish, Rokan Hulu Regency with palm sugar. Rokan Hilir Regency with peanut butter, Dumai City with sweet potato chips, Siak Regency bolu kemujo, Pelalawan Regency with betutu fish, and Pekanbaru City with bolu kemujo.

Seeing the condition of this strategic regency, Riau Province is visited by visitors from various regions and even overseas, both for the purpose of temporary stay, or business and tourism visits. The visits to Riau Province provided an opportunity for Riau to develop regional products as evidence and proof of visiting Riau. Seeing this opportunity, industries that provided such products have developed, ranging from souvenirs, clothing, to food. SMI is a tangible manifestation of community creativity in improving the nation's competitiveness. The products produced by SMIs contain sincerity and attention to the needs that develop in a region. Through competitive products, a product can survive and continue from time to time.

The food industry is currently an industry with high demands because food is a basic necessity and it has specific characteristics and unique Malay taste. Malay cuisine is a differentiator and has an appeal and superiority compared to other cuisines in terms of the raw materials and how to cook them.

The results indicate that competitive advantage in terms of product uniqueness was influenced both directly and indirectly by the implementation of effective strategies, the implementation of effective strategies is influenced by the ability to see opportunities and courage in facing risks in the sense of facing existing competition.

The variable of seeing at opportunities, with two statement items, was stated as quite good, which indicate that the managers of local food SMIs in Riau Province have been sufficiently good at seeing opportunities. The lowest value in this dimension was in the statement "can capture opportunities quickly in developing this business," which shows that the managers of local food SMIs in Riau Province have not been able to capture opportunities quickly. The variables of courage to take risks, with three statement items, was stated as quite good, which indicates that the managers of local food SMIs in Riau Province provides an opportunity to develop risk taking in realizing innovation. The lowest value in this dimension was in the statement "always trying to realize business ideas without thinking too much in developing this food business," which shows that the managers of local food SMIs in Riau Province have not been able to develop the ability to realize business ideas without thinking about the risks.

The effectiveness variable, with four statement items, was stated as quite good, which indicates that the managers of local food SMIs in Riau Province have been quite good at showing effectiveness on Riau local food. The lowest value in this dimension was in the statement "always effective in the use of technology in producing products," which shows that the managers of local food SMIs in Riau Province have not had adequate effective use of technology applied to local food businesses in Riau Province.

Variable of resource uniqueness, with six statement items, was stated as quite good, which indicates that the managers of local food SMIs in Riau Province have been quite good in terms of the uniqueness of the resources. The lowest value in this dimension is in the statement "the products are unique in packaging and stays up-to-date," which shows that the managers of local food SMIs in Riau Province have not been adequate in producing uniqueness in packaging which is an advantage for local food businesses in Riau Province.

The results of this research support the opinions of Siregar, E. I. (2015), Suendro, G. (2010), Supranoto, M. (2009), Machmud, S., \& Sidharta, I. (2013), and Djodjobo, C. V., \& Tawas, H. N. (2014). It is said that building the SMI managers' ability to see opportunities and also building the courage to take risks in developing local SMI products and implementing effective strategies can build a competitive advantage of local food products in the region. 


\section{CONCLUSIONS}

Based on the results of research conducted in the field with 247 respondents, it is concluded that the competitive advantage of food SMIs in Riau Province was influenced by the application of superior strategies, and the application of superior strategies is needed to achieve competitive advantage. Moreover, the implementation of an effective strategy for business managers can be done by building entrepreneurship of the business managers through building the ability to see market opportunities and also building courage in facing competitors with various risks.

\section{REFERENCES}

Alma. 2010. Kewirausahaan untuk Mahasiswa dan Umum. Bandung: Alfabeta.

Anderson, B. S., \& Eshima, Y. 2013. The influence of firm age and intangible resources on the relationship between entrepreneurial orientation and firm growth among Japanese SMEs. Journal of business venturing, 28(3), 413-429.

Brouthers, K. D., Nakos, G., \& Dimitratos, P. 2015. SME entrepreneurial orientation, international performance, and the moderating role of strategic alliances. Entrepreneurship Theory and Practice, 39(5), 1161-1187.

Cassia, L., \& Minola, T. 2012. Hyper-growth of SMEs: Toward a reconciliation of entrepreneurial orientation and strategic resources. International Journal of Entrepreneurial Behavior \& Research, 18(2), 179-197.

Dewanti. 2008. Kewirausahaan, Mitra Wacana Media. Jakarta.

Djodjobo, C. V., \& Tawas, H. N. 2014. Pengaruh orientasi kewirausahaan, inovasi produk, dan keunggulan bersaing terhadap kinerja pemasaran usaha nasi kuning di kota Manado. Jurnal Riset Ekonomi, Manajemen, Bisnis Dan Akuntansi, 2(3).

Eggers, F., Kraus, S., Hughes, M., Laraway, S., \& Snycerski, S. 2013. Implications of customer and entrepreneurial orientations for SME growth. Management Decision, 51(3), 524-546.

Frinces, Z. Heflin. 2011. Be an Entrepreuneur, first edition. Graha Ilmu, Yogyakarta.

Hazlina Ahmad, N., Ramayah, T., Wilson, C., \& Kummerow, L. 2010. Is entrepreneurial competency and business success relationship contingent upon business environment? A study of Malaysian SMEs. International Journal of Entrepreneurial Behavior \& Research, 16(3), 182-203.

Islam, M. A., Khan, M. A., Obaidullah, A. Z. M., \& Alam, M. S. 2011. Effect of entrepreneur and firm characteristics on the business success of small and medium enterprises (SMEs) in Bangladesh. International Journal of Business and Management,
6(3), 289.

Kraus, S., Rigtering, J. C., Hughes, M., \& Hosman, V. 2012. Entrepreneurial orientation and the business performance of SMEs: a quantitative study from the Netherlands. Review of Managerial Science, 6(2), 161-182.

Kreiser, P. M., Marino, L. D., Dickson, P., \& Weaver, K. M. 2010. Cultural influences on entrepreneurial orientation: The impact of national culture on risk taking and proactiveness in SMEs. Entrepreneurship theory and practice, 34(5), 959-984.

Kristanto. 2009. Kewirausahaan Enterpreneurship. Graha Ilmu. Yogyakarta.

Machmud, S., \& Sidharta, I. 2013. Model Kajian Pendekatan Manajemen Strategik Dalam Peningkatan Sektor UMKM Di Kota Bandung (Model Study of Strategic Management Approach In SMEs Sector Improvement In Bandung). Jurnal Computech \& Bisnis, 7(1), 56-66.

Pailis, E. A., \& Suroto, B. Fatkhurahman. 2016. The Influence of Partnerships and Self-concept for the Courage to Take Risks and Their Impact on the Achievements Sought of Small Industries in the City of Pekanbaru. American Journal of Economics, 6(5), 262-269.

Shirokova, G., Vega, G., \& Sokolova, L. 2013. Performance of Russian SMEs: Exploration, exploitation and strategic entrepreneurship. Critical perspectives on international business, 9(1/2), 173-203.

Siregar, E. I. 2015. Model Keunggulan KompetitifUsaha Mikro Kecil Batik. Jurnal Pengkajian KUKM, 9(1).

Suendro, G. 2010. Analisis Pengaruh Inovasi Produk Melalui Kinerja Pemasaran Untuk Mencapai Keunggulan Bersaing Berkelanjutan (Studi Kasus Pada Industri Kecil Dan Menengah Batik Pekalongan) (Doctoral dissertation, Universitas Diponegoro).

Suhendar Sulaiman. 2013. Cara Mudah Menjadi Wirausahawan Sukses, Bahan Ajar Mata Kuliah Kewirausahaan, Universitas Muhammadiyah Jakarta.

Supranoto, M. 2009. Strategi Menciptakan Keunggulan Bersaing Produk Melalui Orientasi Pasar, Inovasi, dan Orientasi Kewirausahaan dalam Rangka Meningkatkan Kinerja Pemasaran (Studi empiris pada: Industri Pakaian Jadi Skala Kecil dan Menengah di kota Semarang) (Doctoral dissertation, Universitas Diponegoro).

Suryana. 2008. Kewirausahaan: Pedoman Praktis Kiat dan Sukses Menuju Sukses. Salemba Empat. Jakarta.

Tang, Z., \& Hull, C. 2012. An investigation of entrepreneurial orientation, perceived environmental hostility, and strategy application among Chinese SMEs. Journal of Small Business Management, 50(1), 132-158.

Tang, Z., \& Tang, J. 2012. Entrepreneurial orientation 
and SME performance in China's changing environment: The moderating effects of strategies. Asia Pacific Journal of Management, 29(2), 409431.

Undang-Undang Republik Indonesia Nomor 20 Tahun 2008 Tentang Usaha Mikro, Kecil, dan Menengah

Undang-Undang Republik Indonesia Nomor 3 Tahun 2014 tentang Perindustrian,

Wahab. 2012. Analisis Kebijakan dari formulasi ke penyusunan model-model implementasi kebijakan public, PT. Bumi Aksara, Jakarta.

Wheelen, T.L., Hunger, J.D., Hoffman, A.N. and Bamford, C.E., 2010. Strategic management and business policy. New Jersey: Prentice Hall.

Zimmerer, Thomas, W. Scarborough, and Norman, M. 2008. Essential of Entrepreneurship and Small Business Management. Tranlator: Yanto Sidik and Endina. Gramedia, Jakarta. 